DOI: https://doi.org/10.18309/anp.v51iesp.1523

\title{
SVEGLIA E AS PAISAGENS SUÍÇAS CLARICEANAS
}

\author{
SVEGLIA AND THE CLARICEAN SWISS LANDSCAPES
}

\author{
Djulia Justen \\ Universidade Federal de Santa Catarina, Florianópolis, Santa Catarina, Brasil \\ djuliajusten@gmail.com
}

Resumo: Este artigo apresenta um percurso pelas narrativas de Clarice Lispector através do relógio Sveglia, protagonista de "O relatório da coisa", de Onde estivestes de noite (1974). O texto teve duas outras versões: "Objecto-relatório-mistério" (1971) e "Um anticonto" (1972). Nestes contos o relógio performa uma alegoria temporal: como despertador do agora. Ela toma outras direções a partir de um pequeno detalhe entre as versões: a identificação do relógio de nome italiano com um relógio suíço. Este pormenor destacado por "Um anticonto" proporciona um passeio por outros textos de Clarice, aqueles compostos por cenas suíças e da primavera. Neles um olhar dialético percorre paisagens, retratos e assim são perfiladas as características helvéticas da neutralidade, organização, previsibilidade, frieza, insensibilidade. Estes traços maquínicos consistem na ânsia suíça de manter à distância os sentidos do corpo, os trânsitos daimonicos e coincidem com a "precisão suíça", expressão idiomática atribuída aos relógios suíços. Essa dura disciplina kantiana e anestética, porém, é quebrada com a primavera e as irrupções sensíveis, imprevisíveis trazidas pela estação. $O$ encontro com as narrativas clariceanas sobre passagens suíças possibilita lançar questões temporais e estéticas acerca do relógio Sveglia como tempo de despertar.

Palavras-chave: Clarice Lispector; Tempo; Despertar; Estética; Susan Buck-Morss

Abstract: This article presents a journey between the narratives of Clarice Lispector through the clock Sveglia, the protagonist of "A report on a thing", of Onde estivestes de noite (1974). The text had two other versions: "Objecto-relatório-mistério" (1971) and "Um anticonto" (1972). In these tales, the clock performs a temporal allegory: as an alarm clock for the now. It takes other directions based on a small detail between the versions: the identification of the Italian name clock with a Swiss watch. This detail highlighted by "Um anticonto" provides a tour between other texts by Clarice, those composed by Swiss and spring scenes. In them, a dialectical look goes through landscapes, portraits and in this way the Swiss characteristics of neutrality, organization, predictability, coldness, insensitivity are profiled. These machinic features consist the Swiss desire to keep the senses of the body and the daimonic transits at a distance. They coincide with the "Swiss precision", an idiomatic expression attributed to Swiss watches. This harsh Kantian and anesthetic discipline, however, is broken with spring and the sensitive, unpredictable outbreaks brought on by the season. The encounter with Clarician narratives about Swiss passages makes it possible to project temporal and aesthetic questions about the clock Sveglia as an awakening time.

Keywords: Clarice Lispector; Time; Awakening; Aesthetics; Susan Buck-Morss

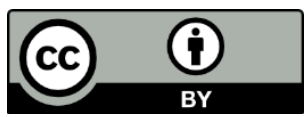




\section{Considerações iniciais}

Um dos traços marcantes das versões de "O relatório da coisa", de Clarice Lispector, consiste em uma voz narrativa que fala sobre e dialoga com um relógio chamado Sveglia. Outra dessas marcas concerne à natureza do texto, que tem um curioso percurso desencadeado pelo menos três vezes no conjunto de narrativas assinadas por Clarice. A começar por "Objectorelatório-mistério" lançado na Revista Senhor (1971). De lá foi deslocado, desmontado e de novo rearmado sob título "Um anticonto" (1985 [1972]), disposto em três partes, no "Caderno B" do Jornal do Brasil. O mesmo fragmento, outra vez desmontado e remontado, foi justaposto aos textos de Onde estivestes de noite, na qual a narrativa ressurgiu desta vez renomeada como "O relatório da coisa." (1999a [1974]).

É impossível não notar o trânsito do fragmento de Sveglia que, em seus deslocamentos, desmonta-se e se recompõe. Constata-se, inclusive, que o movimento do texto remete à construção do mecanismo de um relógio a partir das operações de montagem. Ou seja, o texto é montado de maneira análoga ao objeto maquínico de que trata. Este movimento de composição e disposição textuais apresentado pela narrativa de Clarice assemelha-se a uma montagem literária, princípio conhecido nas artes e na literatura, sobretudo no cinema. Ela também é perceptível em outros textos clariceanos que reutilizam materiais anteriormente publicados, dotando-os de diferenças de ordem variada._É também comum, no âmbito dos escritos clariceanos, a presença de narrativas circulando entre diferentes livros, o que revela a existência de trânsito de envios e reenvios tanto de textos quanto de personagens. Tal procedimento de organizar, desorganizar e reorganizar em agrupamentos feitos de pedaços e restos textuais é análogo ao que Walter Benjamin propõe no Livro das Passagens: a montagem como um método operativo (BENJAMIN, 2018, p. 764).

Se as narrativas clariceanas fazem da montagem literária um procedimento composicional, não seria oportuno tomar como operação de leitura o mesmo caminho, isto é, ler desmembrando e remontando o corpo-textual do relógio Sveglia?

Desde as primeiras linhas as narrativas de Clarice sobre Sveglia parecem ir direto ao ponto, ao centro da questão, ou seja, o tempo.

"Objecto-relatório-mistério":

Esta coisa é a mais difícil de uma pessoa entender. Insista. Vou falar de uma coisa que aos outros parece óbvia. Mas que é extremamente difícil de se saber dela. Pois envolve o tempo. Ou o TEMPO? (LISPECTOR, 1971, p. 107).

"Um anticonto":

Esta coisa é a mais difícil de uma pessoa entender. Insista. Vou falar de uma coisa que aos outros parece óbvia. Mas que é extremamente difícil de se saber dela. Pois envolve o tempo. (LISPECTOR, 1985 [1972], p. 162).

"O relatório da coisa": 
Esta coisa é a mais difícil de uma pessoa entender. Insista. Não desanime. Parecerá óbvio. Mas é extremamente difícil de se saber dela. Pois envolve o tempo. (LISPECTOR, 1999a [1974], p. 57).

Ao modo dos enunciados de uma charada, de uma adivinhação (o que é? o que é?), assim se enuncia a questão do tempo. O que é difícil de entender, mas ao mesmo tempo é óbvio. E para isso os alentos proferidos no modo imperativo, dirigidos ao leitor ou a este outro que inicia o caminho de descobrimento. "Insista" e "Não desanime." É preciso insistir naquilo que continua difícil de saber. Depois, "parecerá óbvio." Pois a charada é evidente e o enunciado traz em si a resposta: "envolve o tempo."

Ao final do parágrafo de "Objecto-relatório-mistério" surge uma pergunta que é suprimida nos textos seguintes. "Ou o TEMPO?” A pergunta ambígua destila um jogo de obviedades através das letras da palavra "tempo" em caixa-alta. Em Objecto textual, Raúl Antelo assinala que o jogo é tão óbvio a ponto de a pergunta "Ou o TEMPO?" ter sido retirada das montagens sequentes do texto. (ANTELO, 1997, p. 7). Mas neste jogo de obviedades e palavras que gritam com seu destaque gráfico, fica a pergunta a ressoar. Qual a diferença entre tempo grafado em letras maiúsculas ou em letras minúsculas? De que instância temporal se fala? Seria possível conjecturar duas noções temporais, uma com letras minúsculas como a passagem das horas, o transcorrer do tempo, a passagem da modernidade, e outra, com letras maiúsculas, aludindo ao tempo como história aberta, segundo a concepção de Walter Benjamin a respeito de uma história que se faz e se refaz fissurando o tempo que se/lhe abre?

Nós dividimos o tempo quando ele na realidade não é divisível. Ele é sempre e imutável. Mas nós precisamos dividi-lo. E para isso criou-se uma coisa monstruosa: o relógio. Não vou falar sobre relógios. (LISPECTOR, 1971, p. 107). (LISPECTOR, 1985 [1972], p. 162). (LISPECTOR, 1999a [1974], p. 57).

O tempo não pode ser fracionado, não é divisível, “é sempre e imutável." Tal fluxo contínuo foi figurado por alguns tipos de relógios nos quais o escorrer fundamenta, por analogia, uma intrigante imagem temporal: dos instantes que caem como os grãos de areia de uma ampulheta, como o deslizar do líquido denso no relógio a azeite, e da água guardada na clepsidra. "Mas nós precisamos dividi-lo." Não seria a razão mercantil do capitalismo que divide o tempo entre as horas e os horários, fazendo do relógio uma coisa monstruosa?

"Mas nós precisamos dividi-lo." Chama atenção esta necessidade declinada na primeira pessoa do plural, a nossa, de seccionar o tempo, mas de outra maneira que não aquela dos imperativos produtivistas. Vale lembrar o que profere o narrador do tema "O relógio de Julius Heckenthorn", de Avalovara, de Osman Lins. A personagem Julius sonha em soar horas inesperadas com a construção de um relógio que pudesse causar uma sensação de espanto e perplexidade suscitada pelo estar diante do tempo. Ele pondera: "Um erro ambicionarmos, para a representação do tempo, engenhos contínuos, nunca interrompidos, sem pausas, renegando a nossa natureza", pois "a própria consciência de que temos de existir não é contínua." (LINS, 1995 [1973], p. 281). Em sua leitura deste trecho do fragmento de Sveglia, Antelo também argumenta em favor das descontinuidades da existência e de tempo. "Como subjetividades históricas, somos tempo; como objetividades sociais, somos distintos.” (ANTELO, 1997, p. 17). 
A consciência que temos da existência e do tempo é abrupta. Interrompida. Divisível. E insiste em ser atravessada por esses movimentos pulsantes e intermitentes do tempo. Tal percepção conduz à imagem do tempo anacrônico compreendida por Walter Benjamin em Origem do drama trágico alemão: um turbilhão no qual se conjugam o "pré" e do "pós", do "agora" e do "outrora", do "devir" e do "declínio." (BENJAMIN, 2011 [1928], p. 18).

Com esta perspectiva de um tempo e de uma existência anacrônicos seria possível ler o relógio, esta coisa monstruosa de uma outra maneira. Como um objeto feito de fragmentos e de montagem de tempos. Por isso, a voz narrativa alerta: "Não vou falar sobre relógios." Mas sobre um relógio.

A marca é Sveglia, o que quer dizer "acorda." Acorda para o que, meu Deus? Para o tempo. Para a hora. Para o instante. (LISPECTOR, 1971, p. 107; LISPECTOR, 1985 [1972], p. 162; LISPECTOR, 1999a [1974], p. 57).

O relógio tem um nome. Em primeiro lugar ele tem uma marca dos objetos serializados da indústria, isto é, a das mercadorias, essas formas coisificadas da nova natureza, condenadas ao tempo infernal do sempre-igual. Em segundo tem uma marca, esta com a qual as coisas são assinadas e assinaladas, índice que elas trazem em si e que manifestam suas qualidades sensíveis e inteligíveis, visíveis, invisíveis. Essas marcas sígnicas, nem semióticas nem semânticas, que Giorgio Agamben destaca em Signatura Rerum (2010), caracterizam a existência das coisas e solicitam habilidade para ler seus vestígios. Portanto triplamente este relógio tem um nome, uma marca, uma assinatura.

Sveglia é nomeado como um relógio singular, um despertador eletrônico do tempo, da hora, do instante. "A marca é Sveglia, o que quer dizer "acorda."” Pelo nome o relógio chama - afinal é pelo nome que podemos chamar as coisas - para o despertar a tempo para o tempo. "Acorda para o que, meu Deus? Para o tempo. Para a hora. Para o instante." Sveglia não é um relógio como os outros em que minutos transcorrem um após o outro. Ele difere por ser inconforme ao tempo linear, espacializado. O instante irrompe nele, o agora que viabiliza a multiplicidade temporal. Isso faz de Sveglia uma alegoria e um chamado ao despertar para o tempo.

Como decifrar essa charada temporal ao mesmo tempo óbvia e impenetrável que os fragmentos clariceanos enunciam desde o início? Como ler o tempo de despertar alegorizado por Sveglia? Para dialogar com estas questões recorto um pequeno trecho de "O surrealismo, o último instantâneo da inteligência europeia”, de Walter Benjamin.

Pois não nos serve de nada sublinhar patética ou fanaticamente no enigmático o seu lado enigmático; muito antes, só penetramos o mistério na medida em que o reencontramos no cotidiano, graças a uma ótica dialética que vê o cotidiano como impenetrável e o impenetrável como cotidiano. (BENJAMIN, 2012 [1929], p. 33).

Parafraseando o autor, é possível dizer que de nada servirá apenas afirmar que o tempo tem seus enigmas, seus mistérios. Só se penetra o mistério temporal, essa charada enigmática, quando ele é entrevisto no cotidiano desde um olhar dialético capaz de captar, de sentir a inquietante estranheza nos objetos, o infamiliar no familiar, o familiar no infamiliar e assim iluminar profanamente as coisas. Não teria sido esse caminho percorrido pela narrativa 
clariceana na montagem de seus despertares temporais através de um olhar dialético para o relógio, este elemento próximo e banal, e com base nele compô-la a partir de iluminações profanas (BENJAMIN, 2012 [1929], p. 33), descrições e proveniências imaginativas, diálogos com Sveglia?

Na direção deste olhar dialético destaco uma passagem sobre as origens misteriosas de Sveglia a partir de ardilosos monólogos com o relógio.

Em "Objecto-relatório-mistério" e "O relatório da coisa":

Mas você tem fraquezas, Sveglia. Eu soube pela tua dona que você precisa de uma capa de couro para protegê-lo contra a umidade. Soube também que você uma vez parou. A dona não se afobou. Deu a "êle-nêle" umas mexidinhas muito das simples e você nunca mais parou. Eu te entendo, eu te perdôo: você veio da Europa e precisa um mínimo de tempo para se aclimatar não é? (LISPECTOR, 1971, p. 108; LISPECTOR, 1999a [1974], p. 58-59).

Em "Um anticonto":

Mas, Sveglia, você tem fraquezas. Soube pela dona que você precisa de uma capa de couro para protegê-lo contra a umidade. Soube também que você uma vez parou. A dona não se afobou: deu a ele-nele uma mexidinha muito da simples e você nunca mais parou para todo o sempre. Eu te compreendo, eu te perdôo: você veio da Suíça e precisou de um mínimo de tempo para se aclimatar, não é? (LISPECTOR, 1985 [1972], p. 163).

Nota-se que a voz narrativa interpela Sveglia na segunda pessoa do singular, "você", ao relatar as fragilidades que lhe são próprias. O "Eu te compreendo", da versão para o $J B$, destaca uma aproximação entre narradora e objeto, uma indulgência com relação às fraquezas por ela descritas. $\mathrm{O}$ "Eu te entendo" sugere uma intimidade, ao passo que insinua uma autoridade da instância narrativa sobre o objeto. Há uma tensão entre empatia e hierarquia.

Tomando Sveglia como mercadoria, há de se notar um tom de deboche quanto ao fato de o relógio ter sido importado. Daí o detalhamento sarcástico implícito na informação de que Sveglia precisa de uma "capa de couro" para protegê-lo da umidade tropical e de "um mínimo de tempo" para se aclimatar, tal como um viajante de terras frias que chega a esta. Na alusão à capa ecoa a maneira sentimental com a qual a burguesia costuma tratar as mercadorias de modo fetichista, como bem observou Walter Benjamin, abrigando-as em estojos, guardando-as cuidadosamente atrás dos vidros, isto é, humanizando-as como se fossem "da casa." (BENJAMIN, 2015, p. 168).

$\mathrm{Na}$ sequência a narração continua a destacar as fragilidades decorrentes do caráter maquínico do relógio, cuja existência é deste modo aproximada da humana, uma vez que também sujeita a falhas e desacertos. "Soube também que você uma vez parou." A descrição da providência banal tomada pela dona para ajeitar Sveglia após ter ele parado chama a atenção pela placidez. "Deu a 'êle-nêle' umas mexidinhas muito das simples." Algumas questões decorrem da menção ao gesto de mexer, no diminutivo, com o sentido específico de ajustar ou reparar. Uma única mexidinha "muito da simples" seria o bastante? Ou, no plural daquelas duas versões: que mexidinhas tão singelas seriam essas, capazes de ajeitar essa mercadoria então supervalorizada, porque importada? Mexidinhas simples ao modo do "jeitinho brasileiro", da gambiarra improvisada para tentar fazer as coisas funcionarem? Mexidinhas muito simples, desprovidas de sapiência técnica e científica, que fazem um objeto de tamanha complexidade, 
curiosamente voltar a andar? Mexidinhas muito das simples, porém misteriosas, que vindo do nada solucionam, de maneira que lemos a confissão, "e você nunca mais parou." Em "Um anticonto" há um adendo: "para todo o sempre." Dá para ajeitar o tempo, dar uma ou umas mexidinhas muito simples, como desmontar e remontar, e ele seguir adiante?

Destaco agora um detalhe acerca da proveniência de Sveglia. Em "Objecto-relatóriomistério" e "O relatório da coisa" surge informado um território amplo, multinacional: "Você veio da Europa." Já em "Um anticonto" o local de fabricação é precisado: "Você veio da Suíça." Poderia parecer insignificante a diferença da versão no $J B$. Entretanto uma minúcia como essa instiga algumas indagações. Que vinculação seria essa entre um relógio suíço e seu nome italiano? De que modo essa despretensiosa associação de Sveglia com um relógio suíço poderia desentranhar relações para impulsionar o tempo disposto pelo relógio clariceano?

Dizer que Sveglia vem da Suíça é inseri-lo na tradição dos relógios suíços, duráveis, precisos e meticulosamente montados. Tem-se, inclusive, algumas expressões idiomáticas relativas à impecabilidade a eles atrelada. Em português, por exemplo, para fazer referência a essas características fala-se de uma "precisão suíça", ou do comparativo "como um relógio suíço", para qualificar um máximo de rigor e correção. Tal escrupulosidade, em contraposição, costuma se referir ao que é feito sem espontaneidade, sem risco nem ousadia, o que exclui o imprevisível.

A identificação de Sveglia como um relógio suíço traria a princípio a imagem alegórica do tempo cronometrado, quantificado, linear, igual a si mesmo, o que soaria incongruente com respeito ao despertador do agora presente no texto clariceano, no qual os instantes dele irrompem. Levando-a em consideração, entretanto, ter-se-ia uma mescla de nacionalidades distintas, isto é, um relógio de procedência suíça com nome italiano. Esse contraste pode apontar algumas direções do despertar temporal de Sveglia. Seria essa combinação referente a leituras gregas do tempo que se cruzam como Cronos, Aion e Kairós? (HAUBERT, 2019, p. 78). Um tempo ao modo do relógio suíço, o tempo de Cronos, da sucessão e da medida, do cronológico, regrado e previsível, porém atravessado pelo tempo de Aion, tempo divino, da eternidade, do fluxo vital que faz a vida nascer e pulsar (Aion também significa aquela parcela de vida recebida), e pelo o tempo de Kairós, o instante oportuno, espontâneo, imprevisível, que insurge e desperta para o agora?

A partir das indagações levantadas, passeio por algumas narrativas de Clarice cujos motes são cenas e paisagens suíças.

Clarice viveu em Berna, na Suíça, entre 1946 e 1949. De lá enviava cartas a suas irmãs. Nelas relatava, entre outras coisas, impressões sobre a cidade. Nas primeiras semanas em solo suíço, em abril de 1946, ela menciona o incômodo com o silêncio e a sobriedade do lugar no qual a leveza dos risos tem aparentemente pouco espaço. "Berna é de um silêncio terrível: as pessoas também são silenciosas e riem pouco. Eu é que tenho tido acessos de riso." (LISPECTOR, 2007, p. 110). O silêncio lhe aparenta ser uma das características mais marcantes da cidade, ainda mais se acompanhado do inverno e da neve, como relata em carta de dezembro de 1947. "E com a neve o silêncio da Suíça parece ficar ainda mais absoluto. Aqui no meu 
quarto não ouço um som.” (LISPECTOR, 2007, p. 179). No terceiro mês vivendo lá, ela pormenoriza suas impressões e compara Berna com outros lugares da Europa. Em carta endereçada à irmã Elisa, de 17 de julho de 1946, perfila:

\begin{abstract}
A Suíça é sólida e quando a gente abre os olhos de manhã sabe que ela está ali onde se deixou. Não tem o caráter de terra magnânima como a Itália, por exemplo, ou a França, onde as coisas são tão espontâneas e variadas que terminam dando certa confusão ao ambiente; aqui cada coisa tem seu lugar, há silêncio e dignidade. Dignidade excessiva, às vezes. Lausanne já é diferente de Berna; as pessoas têm o ar mais vivo, se olham, a cidade é mais larga e parece mais jogada. Enquanto Berna parece que foi recortada; recortaram um riozinho verde e brilhante, junto recortaram um pôr do sol de cor-de-rosa vivo, junto recortaram uma casa que termina aguda e outra que termina rasa; botaram uma ponte aqui, outra ali, recortaram as ruas principais em arcadas (isso deixa as calçadas sempre cobertas como uma casa) (LISPECTOR, 2007, p. 132-133).
\end{abstract}

É possível notar, através percepções da escritora, contrastes entre Berna e outras localidades da Suíça e da Europa, em especial no que tange aos comportamentos humanos. Se a Itália é descrita como terra magnânima, a França como espontânea, porém confusa, ao tratar do país helvético ela se detém em particularidades. Sua avaliação de Lausanne é positiva, já que seus habitantes trocam olhares e desfrutam de maior espaço e liberdade. Berna, por sua vez, parece incomodá-la seja pela quietude das pessoas, seja pelo peso da solidez e moralidade a seu ver excessivas. "Cada coisa tem seu lugar, há silêncio e dignidade. Dignidade excessiva, às vezes."

Na sequência, Berna é descrita como a cidade recortada, na qual cada coisa tem o seu lugar. Isto é, ela foi montada com elementos escolhidos e meticulosamente compostos. Ora, tal descrição de Berna vai ao encontro da "qualidade suíça", ou de "como um relógio suíço", isso porque nela o acento é posto sobre a previsibilidade, a impecabilidade, a frieza nos contatos cotidianos.

A carta abre a possibilidade para a autora exprimir sua sensibilidade e disponibilidade para os outros e para as coisas ao seu redor, e fazer delas matérias propícias para a prática narrativa. Aquilo que afetou a superfície da pele passa a ter o potencial de ser colocado na superfície do papel, e assim poder ser, a posteriori, compartilhado. Além disso, a missiva permite reconhecer mais um movimento composicional. A experiência sensível da escritora de estar em Berna é recolhida e transformada, primeiramente, em narrativa epistolar. A partir daquelas sensações e observações monta-se outras narrativas, desta vez literárias.

A paisagem suíça descrita na carta será, anos depois, trazida à baila em "Berna", de "Fundo de gaveta" de A legião estrangeira (1964), e do póstumo Para não esquecer (s/d [1978]). O conto privilegia o impacto causado pela paisagem suíça aos olhos de um forasteiro — o estranho e estrangeiro àquela cidade.

O forasteiro, tendo diante dos olhos essa beleza perfeita, não saberá talvez elucidar o seu mistério: a cena suíça tem um excesso de evidência e de beleza. Após a primeira sensação de facilidade, segue-se a ideia do indevassável. Cartão-postal, sim. Mas aos poucos a imobilidade e o equilíbrio começam a inquietar. (LISPECTOR, s/d [1978], 181). 
Há um olhar dialético diante da cena de evidência e beleza, que vê o impenetrável na pretensa facilidade da paisagem suíça e sente a inquietante estranheza da imobilidade e do equilíbrio, a ponto de suscitarem mistério. "Berna" é iniciada in media res, ou seja, no meio das coisas, entre o forasteiro e o mistério que este tem frente aos olhos.

Similar ao Unheimliche freudiano (FREUD, 2019 [1919]) a sensação inquietante traz consigo a impressão de que algo foi extirpado, lançado para fora do ser que admira.

Olha-se para as montanhas ao longe, e é tonto e tranquilo o espaço. Mas na pequena cidade alta, de casas e igrejas apertadas por muros que já tombaram, há uma concentração íntima e severa. Na cidade de torres, becos, ogivas e silêncio, o Demônio terá sido expulso para além dos Alpes. Sem o Demônio, restou uma paz perturbadora, marcas de uma vida que se formou com dureza, o punho da reforma, sinais de conquista lenta, aperfeiçoamento obstinado e penoso. (LISPECTOR, s/d [1978], p. 181).

A insistência suíça em manter à distância o Demônio, que a qualquer instante pode vir à luz, é sentida na tensão da concentração e da perturbadora paz que impregnam o cenário. Etimologicamente Demônio vem do grego daimónion, daimon. No politeísmo da religião grega, daimon refere-se a uma divindade ou espírito intermediário entre os seres humanos e os deuses, aquele que faz os trânsitos entre o divino e o mundano e influi diretamente nas ações humanas (PETERS, 1983). Trata-se do gênio inspirador que se liga a cada indivíduo desde o nascimento, colaborando para definir caracteres e destinos. Já na tradição judaico-cristã o Demônio deixa de ser ambíguo e passa a personificar o mal. Em Princípios de espectrologia, Fabián Ludueña Romandini (2016) atenta para os daimons, estes espectros que foram excluídos pelo pensamento da modernidade. Além dessas simbologias, o demônio também seria a expressão para forças ou estímulos interiores que excitam, conturbam os sentidos inteligíveis, exacerbando paixões e emoções. (HOLANDA FERREIRA, 1975, p. 431).

Voltando à narrativa em análise, na descrição da cena suíça da qual o Demônio foi lançado para além dos Alpes, o que teria sido expulso senão o daimon, esse ser de articulação, sempre entre o humano e o divino? A eliminação desse ente de natureza mista, formada pelos extremos só pode ser em razão da sistematicidade e praticidade suíças. A necessidade moral de manter a ordem, a separação dos mundos é feita em nome da higienização do ambiente em que o homem suíço mais do que vive, respira.

Obstinação de manter afastado o Demônio? Obstinação que se trabalha nessa ânsia tão suíça de limpeza, vontade de copiar em terra a clareza do ar, obediência à lei de nitidez que a montanha, na sua implacável fronteira, dita. Vontade de imolar a coisa humana, fatalmente impura e desordenada, à límpida abstração dessa natureza. A ordem não é mais um meio, é uma necessidade em si mesma moral. A ordem é o único ambiente onde um homem suíço pode, na Suíça, respirar. Fora da Suíça, ele se espanta, encantado com aquele Demônio que ele mesmo expulsou. (LISPECTOR, s/d [1978], p. 181-182).

Cabe observar que essa ânsia em manter afastado o Demônio e tudo aquilo que irrompe de sensível e ambíguo na natureza humana pode ser interpretada conforme a proposta de Susan Buck-Morss exposta em "Estética e anestética." Ali a autora critica o esforço de Immanuel Kant de categorizar o sensível em favor de uma potencialização objetiva, que implica em uma virilização. Esta, por sua vez, neutraliza a natureza, tornando-a refratária aos impulsos e 
contatos corpóreos. "Se é que tem corpo, este deve ser impermeável aos sentidos e, por conseguinte, protegido do controle externo. Sua potência se encontra na sua falta de resposta corporal. Ao abandonar os sentidos, ele abre mão do sexo, é claro.” (BUCK-MORSS, 2012, p. 178). Essa "não sensorial e anestética" (BUCK-MORSS, 2012, p. 178) kantiana, e também moderna, quer manter afastada a estética no sentido etimológico da palavra em grego, a Aisthitikos, aquilo que é sentido pelos seres.

A ânsia suíça pela ordem que busca manter separados o sagrado e do profano, o sensível e o inteligível reaparecem em "O medo de errar" (1999b [1969]), recolhido em $A$ descoberta do mundo. Esse pendor pelo método faz parte do perfil do suíço, esta personagem exemplar, tal como delineado pela narradora na resposta que fornece à ardilosa pergunta a "um suíço inteligente." (LISPECTOR, 1999b [1969], p. 230). A ele é perguntado o porquê da inexistência de "pensamento filosófico na Suíça." (LISPECTOR, 1999b [1969], p. 230). A reposta do entrevistado enfatiza que o equilíbrio e a neutralidade são cruciais no modo de ser suíço, comprometido com um princípio de apaziguamento capaz de evitar transtornos resultantes de a população ser formada por três raças distintas, situação potencializada pelo fato de quatro línguas diferentes serem correntes no país.

$\mathrm{Na}$ sequência a narradora interrompe o diálogo e passa a refletir sobre o que escutou. "Assim, quem pensa espera de antemão uma vitória apenas média. As ideias de cada um se encontram e param no seu ponto de contato com as outras." (LISPECTOR, 1999b [1969], p. 230). É um modo suíço, e kantiano portanto, de nunca chegar aos extremos, nem com os outros nem consigo mesmo, haja vista a postura de neutralidade e equilíbrio que, curiosamente, é oposto daquilo que seria próprio dos pensamentos filosófico e sensível. "Ora, o pensamento filosófico é por excelência aquele que vai até o seu próprio extremo. Não pode admitir transigências, senão a posteriori. Nenhuma obra filosófica poderia ser construída tendo como um de seus princípios tácitos a necessidade de se chegar somente até certo ponto." (LISPECTOR, 1999b [1969], p. 230).

Neutralidade e equilíbrio se tornaram basilares para a organização social suíça, da qual decorre uma fórmula de vida ancorada nos caracteres nacionais e kantianos. O mais evidente deles, expressa o fragmento, é a atitude mental da precaução.

A impressão que se tem de um suíço é a de um homem que vive em segurança e, mais do que isso, que sofre da ânsia de segurança. [...] Essa atitude de previdência encontra, a cada momento, motivo de se concretizar. E se estende até onde já seria desejável que se interrompesse. (LISPECTOR, 1999b [1969], p. 231).

A atitude previdente prossegue e tem sua consequência: medo de errar, de se arriscar. A expressão, além de dar título ao texto, imprime uma provocação à 'qualidade suíça', ao 'país da precisão', ao esmero, perfeição e previsibilidade em manter as coisas no lugar, separando sagrado e profano. Como se diz popularmente "errar é humano" e os suíços têm medo daquilo que lhes é mais próprio: o descontrole, o imprevisível, o errático, o imperfeito, o disruptivo. Temor do equívoco, de sair da média e chegar aos extremos dos pensamentos, dos sentidos sensíveis e inteligíveis. $\mathrm{O}$ apego à segurança, entretanto, teria proporcionado aos suíços conquistar um alto estágio civilizatório, com "nobre esforço" e "conquista paciente." Buscam mantê-los com "austera previdência" e enorme "precaução contra o erro." (LISPECTOR, 1999b [1969], p. 231-232).

Esta dura disciplina metódica e rígida usada para manter o estado civilizado não impede que o insuportável emerja e subleve-se em formas inesperadas e desesperadas: suicídios 
silenciosos na ponte de Kirchenfeld. Para evitar que o contágio de irrupções se espalhe os jornais não noticiam tais ocorrências. O texto finaliza com uma conclusão mordaz. "De algum modo há de se pagar a segurança, a paz, o medo de errar.” (LISPECTOR, 1999b [1969], p. 233).

O olhar do forasteiro continua a guiar a descrição da cena de cartão-postal de "Berna", passando agora aos retratos masculino e feminino feitos nos moldes do sacrifício e da ausência de expressividade.

\begin{abstract}
Nas ruas, os rostos ascéticos, economia de expressão. E nessa expressão pacífica e pesada, uma força silenciosa que lembra a do fanatismo. Disse alguém que suíço não é soldado, é guerreiro. Pois se o suíço é guerreiro, a mulher suíça é mulher de guerreiro. É um ser severo e duro, votado para algum sacrifício. Ei-la no concerto da catedral, o rosto sem pintura, impassível, banhando-se, com prazer que mal se manifesta, nos sons do órgão e nas vozes altas do coro, música purificada que responde à alegria austera desse povo. A mulher não se encostará completamente à cadeira, manter-se-á um pouco solene e indecifrável, sem o encanto da moleza, mas com alguma graça puritana que reponta não sei onde, vencendo um modo de se vestir que tem pudor da vaidade. (LISPECTOR, s/d [1978], p. 182).
\end{abstract}

Se a expressividade está ligada aos sentidos sensíveis, nestes retratos estes são obliterados. As descrições corpóreas lembram a imagem do impassível guerreiro kantiano, "o exemplo do homem mais digno de respeito", aquele que é "impermeável a todas as suas informações sensoriais do perigo" (BUCK-MORSS, 2012, p. 160), o que vai favorecer a frieza da maquinização: postura solene, severa, cheia de dignidade, que exclui a moleza sensível do corpo a ponto de evitar lhe dar conforto ao se sentar. Se ao sentido auditivo é permitido ter algum prazer, esse resulta apenas da audição de um tipo de música purificada, com predomínio de sons de órgão e coro de igreja, que pouco reverbera nos corpos para fazê-los dançar. Pode até ser que brote alguma alegria, mas esta pouco transparece. O rosto feminino deve ser contemplativo e sem os atrativos da maquiagem. As vestes devem se adequar a uma "graça puritana" de modo a manter as vergonhas ocultas e menosprezar a vaidade e o desejo de atrair a admiração dos demais.

Este estado austero e de pudor sobre os corpos é alterado com a chegada da primavera. "Berna" descreve este momento como um rompimento.

Esse pudor é vencido na primavera, e timidamente ousa. Aparecem blusas claras, pequenas golas brancas surgem nos vestidos escuros, delicada contribuição feminina à luz. Os velhos se sentam sérios nos jardins: essa é a terra dos velhos respeitáveis. Dos bancos eles contemplam os lagos brilhantes, os Alpes nevados, o ar de apressada alegria em cada ramo. Depois virá o estio, e no morno perfume as linhas se tornam mais ásperas, as flores mais urgentes e violentas, o vento felizmente traz alguma poeira. Esporte, esporte, esporte - que é um desabrochamento sem demônios. O outono vem e escurece águas, não se ouvem sons de caçadas, mas compra-se caça; montanhas, superfícies, pequenas formas, tudo tomará, sob o vento mais frio e uma luz sem sol, uma intimidade de lar. Então vem o inverno: esporte, esporte, esporte. (LISPECTOR, s/d [1978], p. 182-183). 
Se de um lado, a primavera quebra a equilibrada paisagem suíça e permite que os corpos reflitam suas luzes, de outro lado, outono e inverno são similares, escuros, silenciosos. A expressão "esporte, esporte, esporte" se repete duas vezes para anunciar o começo das estações frias. Chega então o inverno com seu "desabrochamento sem demônios": desprovido do irromper daimoníaco que esplandece na ousada, contudo tímida primavera.

Se se puder falar de uma concepção temporal a partir dos meticulosos traços helvéticos, seria próximo de um tempo regular, metrificado e quantificado, monótono. Neste caso, os viventes estariam diante de um dos regimes temporais de Cronos, o tempo da mensuração dos ciclos, da delimitação, da circularidade (PELBART, 1998, p. 71). Não à toa a paisagem em "Berna" é atravessada por uma temporalidade de aspecto cronológico: as estações do ano. São períodos marcados pela sucessão, pelos ciclos. Eles imprimem ritmos entediantes, cansativos, insuportáveis. Indiferentes, nada ousados. Nesse ínterim algo irrompe na narrativa de Clarice. A primavera chega. Ela anima os habitantes para que ousem, com acanho, entregarse aos prazeres, dos corpos, das cores, das flores, dos cheiros, dos cantos naturais. É importante ressaltar que as insurgências revolucionárias são chamadas de Primaveras: a interrupção dos marasmos e do subjugo.

A primavera clariceana não aportaria a confluência de temporalidades que rompem os estribos de Cronos e seus comandos? Não introduziria uma convergência de temporalidades na quais explodem dois presentes, o da subversão pelo fundo e o da efetuação das formas, o ser atualizado na superfície e o devir-louco proveniente das profundezas? E entre eles não poderia surgir um tempo-outro, o de Aion? Segundo Deleuze em Lógica do sentido (2015), o instante aiônico insistentemente secciona passado e futuro, insere-se entre o "já foi" e o "ainda não", ensejando os devires temporais e sensíveis. Emerge aí a temporalidade estoica relativa aos incorporais, as paixões, os afetos na superfície dos corpos. Não estariam essas confluências presentes no relógio Sveglia e em seu chamado para o despertar do tempo, a tempo, há tempo?

A primavera suíça ganha destaque em pelo menos três relatos de $A$ descoberta do mundo: "Suíte da primavera suíça" (1999b [1967]), "Lembrança de uma fonte, de uma cidade" (1999b [1970a]) e "Lembrança de uma primavera suíça" (1999b [1970b]). A repetição da palavra "lembrança" nos títulos é significativa. Apontaria ela para traços desses instantes primaveris? Lembrança consiste naquilo que vem à memória, que surge inesperadamente, em um momento de distração, distensão ou mesmo em um instante de perigo. Como uma luz, como uma imagem. Seriam eles lampejos?

Em "Lembrança de uma fonte, de uma cidade", a narradora relata a espera pela insurgência da primavera, o que lhe permite sobreviver à monotonia do inverno bernense.

Na Suíça, em Berna, eu morava na Gerechtigkeitgasse, isto é, Rua da Justiça. Diante de minha casa, na rua, estava a estátua em cores, segurando a balança. Em torno, reis esmagados pedindo talvez uma exceção. No inverno, o pequeno lago no centro do qual estava a estátua, no inverno a água gelada, às vezes quebradiça de fino gelo. $\mathrm{Na}$ primavera gerânios vermelhos. As carolas debruçavam-se na água e, balança equilibrada, na água suas sombras vermelhas ressurgiam. Qual das duas imagens era em verdade o gerânio? igual distância, perspectiva certa, silêncio da perfeição. E a rua ainda medieval: eu morava na parte antiga da cidade. $\mathrm{O}$ que me salvou da monotonia de Berna foi viver na Idade Média, foi esperar que a neve parasse e os gerânios vermelhos de novo se refletissem na água. (LISPECTOR, 1999b [1970a], p. 270). 
"Suíte da primavera suíça" (1999b [1967]) apresenta o esperado encontro com a estação revigoradora, provida de luz e musicalidade. Ao modo da peça musical referida no título, o fragmento intercala elementos primaveris com refrões formados por frases curtas e palavras repetidas. A brisa, as folhas, os espirros, os perfumes das flores portam sonoridades que chegam aos sentidos sensíveis.

\begin{abstract}
Inverno de Berna em túmulo a se abrir - e eis o campo, eis mil ervas. Folhas novas, folhas, como vos separar do vento. Um espirro e depois outro, espirros da primavera, resfriada e atenta atrás da vidraça. Fios de aranha nos dedos, o poço revelado no jardim - mas que perfume de aço novo vem das miúdas flores amarelas e amarelinhas. Folhas, folhas, como vos separar da brisa. Onde me esconder nesta aberta claridade? (LISPECTOR, 1999b [1967], p. 39).
\end{abstract}

A insone primavera desperta o contato com o outro, as aberturas ao espaço externo onde as pessoas circulam e se encontram. A vida contida desabrocha às margens dos rios, nas calçadas, nos cinemas, junto com as flores e os zumbidos de mosquitos. Portas e janelas abertas transmitem a "leveza desperta." (LISPECTOR, 1999b [1967], p. 40).

O aflorar da sensibilidade acordada pelas aberturas ao espaço conduz ao sono no qual surgem imagens oníricas. Estas promovem a "tendência primaveril ao roubo." Essa disposição pode ser lida como "arrombo", "ímpeto", isto é, a manifestação intensa de prazer, de êxtase.

Nesta dormente primavera, no campo o sonho das cabras. No terraço do hotel o peixe no aquário. E nas colinas o fauno solitário. Dias, dias, dias e depois - no campo o vento, o sonho impudente das cabras, o peixe oco no aquário - tua súbita tendência primaveril ao roubo, e o fauno já corado em saltos solitários. Sim, mas até que venha o verão e amadureça para o outono cem mil maçãs (LISPECTOR, 1999b [1967], p. 40).

Repara-se que a inclinação sensual da primavera é colocada através de animais (peixes e cabras) e de um fauno - uma divindade romana com corpo humano, mas pernas e chifres de cabra. Eles sugerem mesclas de sensualidade e animalidade encontradas nos sentidos sensíveis. No campo das artes, as referências ao fauno corado são variadas. A começar pelo poema de Stéphane Mallarmé, "A tarde de um fauno" [L'après-midi d'un faune], escrito em 1865 e publicado em 1876, acompanhado de ilustrações de Édouard Manet. A criatura ainda serviu como tema para outras duas expressões artísticas de forte repercussão na Europa do final do século XIX e princípio do século XX: o poema sinfônico Prelúdio à tarde de um fauno (18921894), de Claude Debussy, e o balé que o coreografa, criado por Vaslav Nijinski, em 1912. (SINICO; GERLING, 2016, p. 69-70).

Os impulsos e aberturas primaveris, contudo, duram pouco (no relato, por instantes): até que o verão surja. Depois destes arrebatamentos sensíveis, fica a pergunta: como retornar à ordenação cronológica e a ânsia suíça de higienização e previsibilidade?

Ao modo de uma variação sobre o mesmo tema, a cena da primavera dormente de "Suíte da primavera suíça" é estendida em "Lembrança de uma primavera suíça." (1999b [1970b]). Nela se expõe o eriçamento do instante primaveril. 
Essa primavera era bem seca, e o rádio estalava captando sua estática, a roupa se eriçava ao largar a eletricidade do corpo, o pente levantava os cabelos imantados, era uma dura primavera. E muito vazia. De qualquer ponto em que se estava partia-se para o longe: nunca se viu tanto caminho. Falava-se pouco; o corpo pesava como seu sono; os olhos estavam grandes e inexpressivos. No terraço estava o peixe no aquário, tomamos refresco olhando para o campo. Com o vento, vem do campo o sonho das cabras. Na outra mesa do terraço, um fauno solitário. Olhamos o copo de refresco e sonhamos estáticos dentro do copo. "O que é que você disse?" "Eu não disse nada". Passavam-se dias e mais dias. Mas bastava um instante de sintonização e de novo captava-se a estática farpada da primavera: o sonho imprudente das cabras, o peixe todo vazio, uma súbita tendência ao roubo de frutas, o fauno coroado em saltos solitários. "O quê?" "Nada, eu não disse nada". Mas eu percebia um primeiro rumor, como um coração batendo debaixo da terra. Quieta, colava meu ouvido na terra e ouvia o verão abrir caminho por dentro, e meu coração embaixo da terra, oh nada! eu não disse nada! - e sentia a paciente brutalidade com que a terra fechada se abria por dentro em parto, e sabia com que peso de doçura o verão amadureceria 100 mil laranjas, e sabia que as laranjas eram minhas — só porque eu assim queria (LISPECTOR, 1999b [1970b], 315-316).

Um bloco denso de texto sem parágrafos nem cortes apresenta uma imagem primaveril seca, dura, vazia. A ambiguidade presente na palavra "estática" conduz à conjunção dos extremos da benjaminiana dialética da imobilidade, e seu correlato tempo em suspensão (BENJAMIN, 2012 [1940], p. 250): o torpor do corpo pesado, sonolento, em contraste com os movimentos do vento, dos ruídos das ondas radiofônicas, da eletricidade capaz de eriçar cabelos e roupas.

Os dias passam ambiguamente estáticos até que em instantes se conecta com a "estática farpada da primavera." Esta é descrita de maneira similar à tendência aos arroubos primaveris. "O sonho imprudente das cabras, o peixe todo vazio, uma súbita tendência ao roubo de frutas, o fauno coroado em saltos solitários." A sensibilidade se inflama, se eriça a ponto de captar no ar o invisível e o inaudível dos toques elétricos, dos diálogos quase telepáticos. "O que é que você disse?" "Eu não disse nada". "O quê?" "Nada, eu não disse nada". A resposta que a princípio parece ser negativa, traz algo em si, pois ao enunciar "Nada, eu não disse nada" diz alguma coisa.

Sintonizar-se com a estática farpada da primavera é contactar-se com os sentidos sensórios. Sentir o rumor, colar os ouvidos na terra e ouvir o tempo que está por vir. O que brota das profundezas também está na superfície de si e murmura alguma coisa dotada de sensações que escapam ao inteligível. "E meu coração embaixo da terra, oh nada! Eu não disse nada!"

\section{Considerações finais}

Os instantes primaveris nas narrativas de Clarice insurgem, porém apenas por um átimo. Logo retorna a frieza, a mecanicidade, o tédio, a monotonia, o peso, a insensibilidade. Como se as confluências temporais e sensíveis alegorizadas pelas exalações da primavera fossem efêmeras. Uma pequena fresta. Um lampejo fugaz. Uma lembrança evanescente. Como uma janela que se abre e se fecha como em um piscar de olhos. Um Kairós cuja chance se esvai, o que impede que seja possível agarrá-lo com as mãos.

Depois da extensa colheita de cenas suíças e irrupções primaveris nas narrativas clariceanas, a questão da suposta proveniência suíça do relógio Sveglia continua a intrigar. Se 
Sveglia é este relógio no qual os irromperes temporais surgem, e se estes pouco duram, tal os lampejos da primavera suíça, de que modo fazer para que estes instantes estejam mais vezes presentes? De que forma fruir das afluências sensíveis e temporais de Aion e Kairós e liberarse dos estribos de Cronos? A diferença reside no nome do relógio: Sveglia. A palavra italiana remete ao verbo "acordar" e abre caminho para as sensibilidades necessárias para apreender as confluências temporais. O desdobramento da palavra Sveglia e a relação com o despertar temporal pode ser conferido na tese SVEGLIAMAQUIA, instantes de despertar em Clarice Lispector. (JUSTEN, 2020).

\section{Referências}

AGAMBEN, G. Teoría das signaturas. In: AGAMBEN, G. Signatura rerum. Sobre el método. 1. ed. Traducción: Flavia Costa e Mercedes Ruvituso. Barcelona: Editorial Anagrama, 2010, p. 43-107.

ANTELO, R. Objecto textual. 1. ed. São Paulo: Fundação Memorial da América Latina, 1997.

BENJAMIN, W. O surrealismo, o último instantâneo da inteligência européia. In:

BENJAMIN, W. Magia e técnica, arte e política. Obras escolhidas. 8. ed. vol 1. Tradução: Sergio Paulo Rouanet. São Paulo: Brasiliense, 2012, p. 21-36. [1929].

BENJAMIN, W. Sobre o conceito de história. In: BENJAMIN, W. Magia e técnica, arte e política. Obras escolhidas. 8. ed. vol 1. Tradução: Sergio Paulo Rouanet. São Paulo: Brasiliense, 2012, p. 241-252. [1940].

BENJAMIN, W. Prólogo epistemológico-crítico. In: BENJAMIN, W. Origem do drama trágico alemão. 2. ed. Tradução: João Barrento. Belo Horizonte: Autêntica, 2011, p. 7-27. [1928].

BENJAMIN, W. Passagens. 2. ed. vol. 1, 2 e 3. Organização da edição brasileira de Willi Bolle. Tradução: alemão de Irene Aron; tradução: francês de Cleonice Paes Barrento Mourão. Belo Horizonte: Editora UFMG, 2018.

BENJAMIN, W. Parque central. In: BENJAMIN, W. Baudelaire e a modernidade. 1. ed. Tradução: João Barrento. Belo Horizonte: Autêntica, 2015, p. 151-189.

BUCK-MORSS, S. Estética e anestética: uma reconsideração de A obra de arte de Walter Benjamin. In: BENJAMIN, W.; SCHÖTTKER, D.; BUCK-MORSS, S.; HANSEN, M. Benjamin e a obra de arte: técnica, imagem, percepção. 1. ed. Tradução: Vera Ribeiro. Rio de Janeiro: Contraponto, 2012, p. 155-204.

DELEUZE, G. A lógica do sentido. 5. ed. Tradução: Luiz Roberto Salinas Fortes. São Paulo: Perspectiva, 2015.

FREUD, S. O infamiliar [Das Unheimliche]. 1. ed. Tradução: Ernani Chaves e Pedro Heliodoro Tavares. Belo Horizonte: Autêntica, 2019. [1919]. 
HAUBERT, L. E. Apontamentos sobre a questão do tempo na Grécia: Kaıрó, X Xóvo Aíwv. PROMETHEUS, v. 11, n. 31, p. 53-71, Set.-Dez. 2019. ISSN: 2176-5960.

Disponível em: https://seer.ufs.br/index.php/prometeus/article/view/10676. Acesso em: 12 fev. 20

HOLANDA FERREIRA, A. B. Novo Dicionário Aurélio. 1. ed. Rio de Janeiro: Nova Fronteira, 1975.

JUSTEN, D. SVEGLIAMAQUIA, instantes de despertar em Clarice Lispector. 2020. Tese (Doutorado em Literatura) - Pós-graduação em Literatura. Universidade Federal de Santa Catarina, Florianópolis. 2020.

LINS, O. Avalovara. 5. ed. São Paulo: Companhia das Letras, 1995. [1973].

LISPECTOR, C. Objecto-relatório-mistério. Senhor. São Paulo: Inter. Editores S.A., v.9, p. 107-112, Set. 1971.

LISPECTOR, C. O relatório da coisa. In: LISPECTOR, C. Onde estivestes de noite. Rio de Janeiro: Rocco, 1999a, p. 57-64. [1974]

LISPECTOR, C. Lembrança de uma fonte, de uma cidade. In: LISPECTOR, C. A descoberta do mundo. Rio de Janeiro: Rocco, 1999b, p. 270. [1970a].

LISPECTOR, C. Lembrança de uma primavera suíça. In: LISPECTOR, C. A descoberta do mundo. Rio de Janeiro: Rocco, 1999, p. 315. [1970b].

LISPECTOR, C. O medo de errar. In: LISPECTOR, C. A descoberta do mundo. Rio de Janeiro: Rocco, 1999b, p. 230-232. [1969].

LISPECTOR, C. Suíte da primavera suíça. In: LISPECTOR, C. A descoberta do mundo. Rio de Janeiro: Rocco, 1999b, p. 39-40. [1967].

LISPECTOR, C. Minhas queridas. 1. ed. Organização de Teresa Montero. Rio de Janeiro: Rocco, 2007.

LISPECTOR, C. Para não esquecer. 1. ed. São Paulo: Círculo do Livro, n/d. [1978].

LISPECTOR, C. Um anticonto. In: RANZOLIN, C. R. Clarice Lispector cronista no Jornal do Brasil (1967-1973). 1985. Dissertação (Mestrado em literatura) - Departamento de Línguas e Literaturas Vernáculas. Universidade Federal de Santa Catarina, Florianópolis, 1985, p. 161-167.

PELBART, P. P. O tempo não-reconciliado. 1. ed. São Paulo: Perspectiva/FAPESP, 1998.

PETERS, F. E. Daimon. In: PETERS, F. Termos Filosóficos Gregos: Um Léxico Histórico. Tradução: Beatriz Rodrigues Barbosa. 2. ed. Lisboa: Fundação Calouse Gulbenkian, 1983. Disponível em: https://sites.google.com/view/sbgdicionariodefilosofia/daimon. Acesso em: 8 fev. 2020. 
ROMANDINI, F. L. Principios de espectrologia (La comunidad de los espectros II). 1. ed. Buenos Aires: Miño y Dávila, 2016.

SINICO, A.; GERLING, C. Análise temporal e comparação de gravações do excerto orquestral para flauta do Prélude à l'après-midi d'un faune de Claude Debussy. Música em perspectiva, v. 9, n.1, p. 69-102, 2016. ISSN: 2236-2126. DOI:

http://dx.doi.org/10.5380/mp.v9i1.48409.

Recebido em: 21 de outubro de 2020

Aceito em: 10 de novembro de 2020

Publicado em Dezembro de 2020 